\title{
化学反応によって誘起される触媒粒子の化学走性の発現
}

\author{
山本 大吾*, 栁谷 拓也, 井尾 祐斗, 塩井 章久
}

\section{Chemotactic Motion of Catalytic Particles Induced by Chemical Reactions}

\author{
Daigo Yamamoto*, Takuya Yanagidani, Yuto Io and Akihisa Shioi
}

Received 9 August 2017; Accepted 17 October 2017

\begin{abstract}
Several research groups including us had reported that catalytic particles with asymmetric composition or morphology exhibit autonomous motions in a homogeneous solution containing reactant. In this study, we provide asymmetric environment where unsteady or quasi-steady gradient of a reactant (ethanol) is formed, although we use spherical catalytic particles made of single metal $(\mathrm{Pt})$. As a result, we found that even spherical particles exhibit specific motility, chemotaxis that objects move along concentration gradient of specific chemical species. In our system, Pt catalytic particles show translation toward the area with higher concentrated reactant (ethanol). Such a new phenomenon is expected to apply to chemical systems such as power source of micromotors and catalytic reaction systems with high reaction efficiency, due to particles' motility.
\end{abstract}

Keywords: Chemotaxis, Catalytic particle, Active matter, Ethanol.

\section{1. 緒言}

「粒子の運動・移動」という言葉から何を想像するだろ うか。本誌の主要読者である粉体工学を専門とする研究 者は, 粉体工学において馴染みの深い「ブラウン拡散（運 動) 」,「重力沈降」,「電気泳動」, …..などを思い浮かべ るのではないだろうか。これらの運動は周囲のポテンシャ ル場の勾配に沿った平衡論に基づく受動的な運動 (Passive Motion) である。一方で, 粒子と同程度のサイ ズであってもバクテリア・アメーバなどの「微生物の運 動・移動」という言葉ではどういうイメージを持ったで あろうか。上述の受動的な運動ではなく，自らが意思を 持って行動する，ポテンシャル場に依存しない（たとえ ば斜面も登ることのできる) 能動的な運動 (Active Motion）を思い浮かべるのではないだろうか。筆者らは 同じ「運動」というワードでも, 生物／非生物系で齟䶣 をきたすことに疑問を感じる。

化学工学あるいは粉体工学においてソフトマター (Soft Matter）という言葉が浸透して久しいが, ソフトマター の新たな応用展開として, 上述の生物模倣的な能動運動 を行うソフトマターの研究が近年注目されており, これ

\footnotetext{
粉体工学会 2017 年度春期研究発表会 BP 賞受賞研究

同志社大学 理工学部化学システム創成工学科

( ₹ 610-0321 京都府京田辺市多々羅都谷 1-3)

Department of Chemical Engineering and Materials Science, Doshisha University

(1-3 Tatara Miyakodani, Kyotanabe, Kyoto 610-0321, Japan)

* Corresponding Author dyamamot@mail.doshisha.ac.jp
}

をアクティブソフトマター（Active Soft Matter）という。 近年では, 特に化学反応によって能動運動を発現するア クティブソフトマターの研究が盛んに行われており, 均 一な反応溶液中での触媒粒子の能動運動が数多く報告さ れている。しかしながらそのほとんどの研究では, 1. 粒 子の前部・後部で反応の非対称性を生み出すために触媒 活性の異なる物質を組み合わせたヤヌス粒子が使われて いる，2. 同一の反応物質（過酸化水素）が用いられてい る, という特徴があり, 多くの先行研究において質的な 違いはさほどないように筆者らは感じていた[1-3]。一 方, 本研究室ではこれまでに何の工夫もない単成分の $\mathrm{Pt}$ 触媒粒子が過酸化水素だけでなくエタノールなどの有機 燃料を含む水溶液中でも, 触媒粒子周りでエ夕ノールの 酸化反応が起こることによって, 形状に依存した能動運 動 (並進, 自転, 公転運動)を行うことを見出してきた $[4,5]$ 。 ここで, 我々の研究を含む既存の研究では, 触媒粒子 自体に非対称性（組成あるいは形状）を与えることで能 動運動を実現している。本論文では粒子自体に非対称性 を付与するのではなく外部環境に非対称性を与えること を考え，化学走性（走化性：Chemotaxis）に注目した。 化学走性とは, 生物が特定の化学物質の濃度勾配に対し て方向性を持った行動をおこなう現象であり，栄養物質 の確保や毒性物質からの退避などに役立っている。触媒 粒子の化学走性についての先行研究として, Hong らは反 応物質である過酸化水素の濃度勾配を作製することで触 媒粒子の化学走性を実現している。しかしながら, ヤヌ ス粒子を使用しているために, 二つの非対称性（粒子の 
(a)

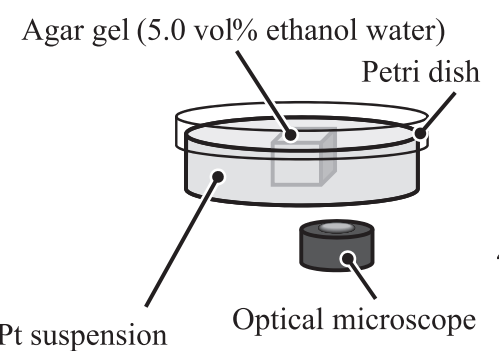

(5.0 vol \% tert-butyl alcohol water) (b)

Bird-view

Side-view

1.0 vol\% ethanol water

$1.0 \mathrm{vol} \%$ ethanol water

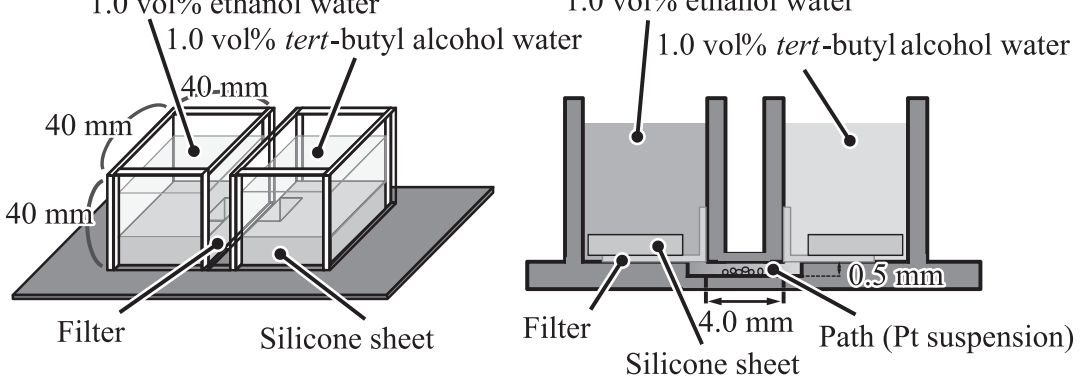

Fig. 1 Schematic illustrations of the experimental setup for the formation of (a) unsteady and (b) quasi-steady concentration gradient of ethanol

組成，外部環境）を同時に与えており，化学走性の発現 機構に最低限必要な物理的因子の特定は困難となってい る[6]。また, 反応溶液中に形成される濃度勾配は非定常 状態であり，定量的な解析が不可能である。さらに，過 酸化水素を反応物質として使用した系では，反応生成物 として酸素ガスを含むために，実験装置内の随所で発生 した気泡によって粒子の運動に影響をおよぼす可能性が ある。以上の観点から, 本研究では球形から単成分の $\mathrm{Pt}$ 触媒粒子を用い，反応生成物に気体を含まないエ夕ノー ルの濃度勾配を作製して, 外部環境にのみ非対称性を与 えた系に関して化学走性を発現させることを目的とした。

\section{2. 実験方法}

\section{1 非定常濃度勾配下での触媒粒子の観察}

実験はすべて室温 $\left(20 \sim 25^{\circ} \mathrm{C}\right)$ で扔こなった。Fig. 1a に示す装置を用いて，エタノールを含む寒天ゲルから Pt 触媒粒子サスペンションに向かってエ夕ノールを拡散さ せることで，エタノールの非定常濃度勾配を作製した。 まず，ビーカーに寒天粉末（和光純薬） $1.2 \mathrm{~g}$ と超純水 $38 \mathrm{~mL}$ を入れ, 加熱摚拌した。寒天が溶解した後, エ夕 ノール（純度 $99.5 \%$ ：和光純薬）を $2 \mathrm{~mL}$ 加えて摚拌し, ペトリ皿に移して冷ますことで， 5.0 vol\%のエタノール 水溶液を含んだ寒天ゲルを作製した。次に，Pt 触媒粒子 サスペンションの作製法を示す。分散媒として $5.0 \mathrm{vol} \%$ の tert-ブチルアルコール（純度 $99.0 \%$ ：東京化成）を含 む水溶液を用い, この水溶液 $40 \mathrm{~mL}$ に対して Pt 粉末 (公 称值 $1 \mu \mathrm{m}$ : ニラコ) 数 $\mathrm{mg}$ を加え, 超音波振動機を用い て分散させた。ここで，tert-ブチルアルコールはほとん ど酸化されない不活性物質であるが，エタノールが拡散 する際に生じる浸透圧差・密度差による対流の影響を軽 減するために加えている。直径 $60 \mathrm{~mm}$ のペトリ皿の中央 に $1 \mathrm{~cm}$ 角に切ったエタノール含有ゲルを配置し， Pt 触 媒粒子サスペンションを注いだ後, 光学顕微鏡を用いて Pt 粒子の運動を観察した。この時，外気の対流および分 散媒蒸発の影響を防ぐためにペトリ皿に蓋をした。また, $\mathrm{Pt}$ に比べて触媒活性のきわめて低い $\mathrm{Au}$ 粒子を含む粒子 サスペンション（公称值 $1 \sim 2 \mu \mathrm{m}$ : ニラコ）を用いた対 照実験も行った。ここで，走査型電子顕微鏡（SEM） （JSM-7500FD，JEOL）の観察によって，Pt および $\mathrm{Au} の$
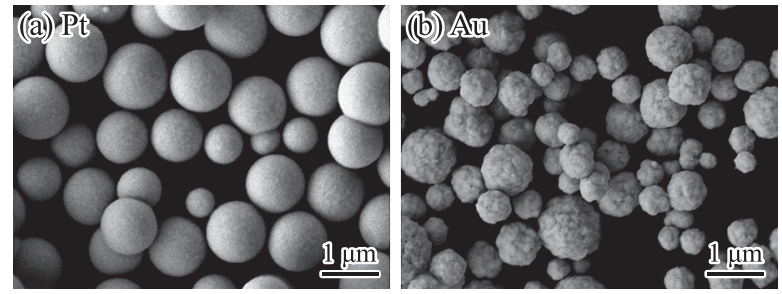

Fig. 2 SEM images of (a) Pt (catalytic) and (b) Au (inert) particles used in the experiment

一次粒子がおおむね球形であることを確認している (Fig. 2)

\section{2 擬定常濃度勾配下での触媒粒子の観察}

Fig. 1bのような装置を用いてエタノールの擬定常濃度 勾配を作製した。厚さ $1 \mathrm{~mm}$ のアクリル板の中央に長さ $6 \mathrm{~mm}$, 幅 $6 \mathrm{~mm}$, 高さ $0.5 \mathrm{~mm}$ の流路を設け, その両端に 液溜めを設けた。この流路の中央 $4 \mathrm{~mm}$ の範囲に, 以下 の手順でエタノールの擬定常濃度勾配を作製し, 流路の 中央付近を観察した。濃度勾配の作製のために，まず流 路内には超純水を分散媒とした Pt 触媒粒子サスペンショ ン $0.2 \mathrm{~mL}$ を注入し, 濡らしたろ紙で流路口をふさいで凹 型シリコンシートで固定した。その後, 両端の液溜めに 1.0 vol\%の tert-ブチルアルコール水溶液を $29.5 \mathrm{~mL}$ ずつ注 入し，対流が収まるまで 1 時間静置してからこの流路中 央部に関して粒子の運動の観察を開始した。さらにその $60 \mathrm{~s}$ 後に左右の液溜めにそれぞれ $60 \mathrm{vol} \%$ のエタノール水 溶液と $1.0 \mathrm{vol} \%$ の tert-ブチルアルコール水溶液を $0.5 \mathrm{~mL}$ ずつ注入して, 左右の液溜めが $1.0 \mathrm{vol} \%$ のタノール水 溶液と tert-ブチルアルコール水溶液になるようにした。 以上の操作によって, 流路内にエタノールが含まれてい ない状態で粒子を観察した後, エ夕ノールの擬定常濃度 勾配下において同一の粒子の運動を観察することが可能 となる。本実験でも， 2.1 節と同様，不活性の $\mathrm{Au}$ 粒子サ スペンションを用いて対照実験をおこなった。

\section{3. 実験結果および考察}

\section{1 非定常濃度勾配下での触媒粒子の観察}

化学走性が発現するか否かをまず確認するため, 2.1 節 で示したように簡便な装置を用いて, 非定常濃度勾配下 での Pt 触媒粒子の運動を観察した。観察結果の典型例を 

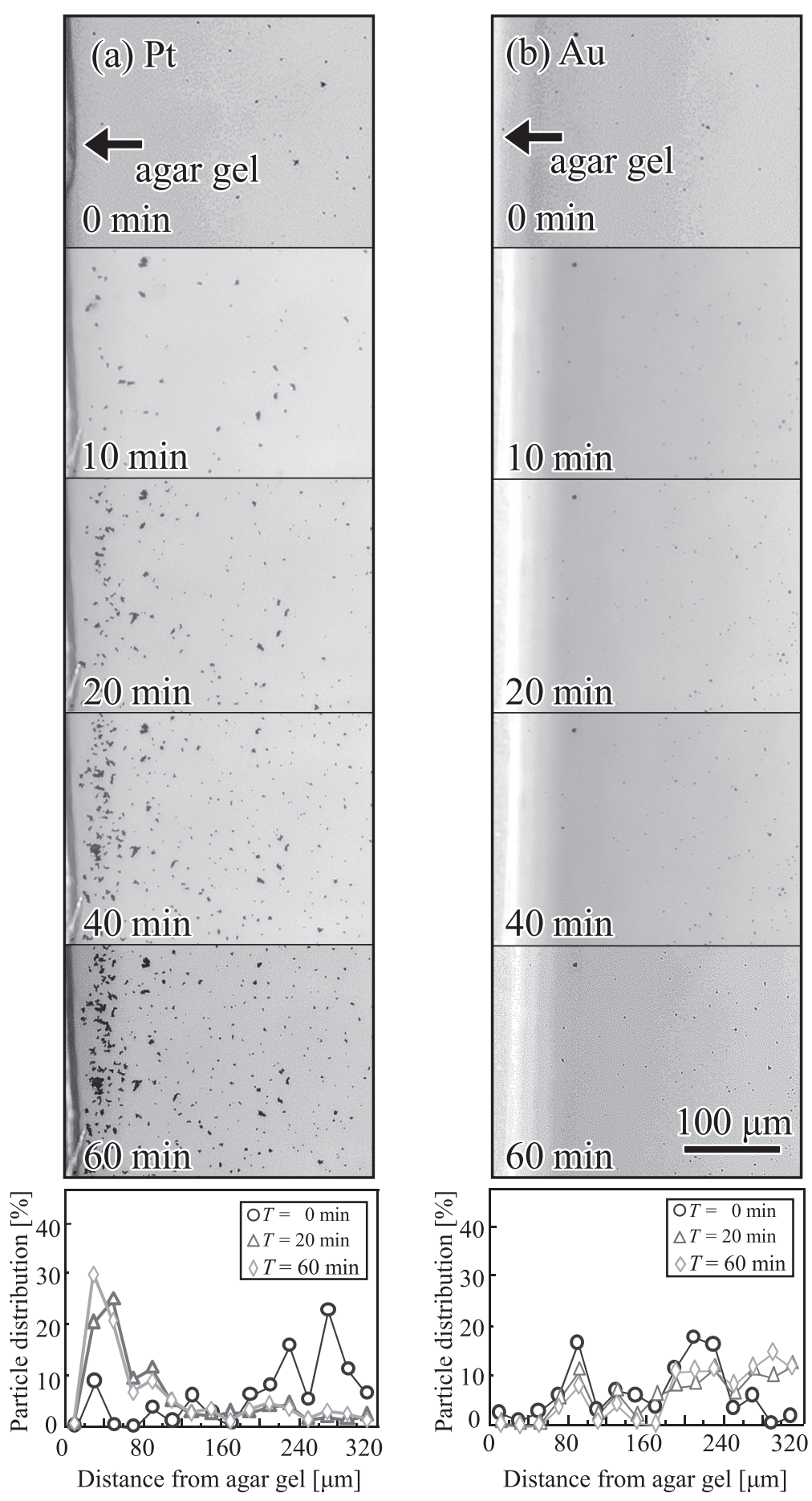

Fig. 3 Optical images and time-dependent distributions of (a) $\mathrm{Pt}$ and (b) $\mathrm{Au}$ particles under unsteady concentration gradient of ethanol

Fig. 3 に示す。Fig. 3aでは, ペトリ皿に溶液とゲルをセッ トしてすぐに観察を開始しており，顕微鏡像の左端にゲ ルが存在している。観察開始時間 $(t=0 \mathrm{~min})$ では, $\mathrm{Pt}$ 粒子はある程度一様に分布していたが，時間が経過する につれてゲル近傍に集まる様子が見られた。一方，触媒 活性の低い $\mathrm{Au}$ 粒子は，特定の位置に集まる様子は見ら れず分散したままであった（Fig. 3b）。このことから，エ タノールや tert-ブチルアルコールの拡散などによる対流 の影響は排除できていることが分かる。

Fig. 3a, b のスナップショットをもとに, Pt および Au
粒子の分布の変化を調べ, 統計的な検討を行った。 $t=0$, 10, 20, 40, 60 min での静止画像を二值化処理し, ゲルの 先端から $20 \mu \mathrm{m}$ ごとに領域を区切ってそれぞれの区間に ある $\mathrm{Pt}$ および $\mathrm{Au}$ 粒子の面積の総和を計算して分布を求 め, Fig. 3 下に示した。ここで, スナップショットは $0.5 \mu \mathrm{m} / \mathrm{pix}$ であり, 一次粒子を十分に計測できているこ とを確認している。横軸が画像の左端に存在する寒天ゲ ルからの距離, 縦軸が画像全体に対して幅 $20 \mu \mathrm{m}$ の区間 にある粒子の面積の割合を示している。Pt 粒子は, $t=$ 0 min ではおよそ一様に分布していたが, 時間が経過す 
るに従い，左側のゲル近傍に粒子が多く分布していくこ とが分かる。一方 $\mathrm{Au}$ 粒子は, 時間が経過しても明確な ピークは現れず，ランダムに分布している。これらの結 果より, Ptの触媒活性によって反応が起こり, 化学走性 を発現する駆動力が生じたと考えられる。ただし，Pt 粒 子がゲルに向かう運動の再現性は 5 割程度であり，粒子 がランダム運動を行う，あるいは静止して動かない場合 もあり,これらの原因については検討する必要があると 考えられる。

ここで，エタノールの濃度勾配下において Pt 粒子がエ タノールの拡散源である寒天ゲルに向かって運動する化 学走性を示すメカニズムについて考察する。我々の過去 の研究で, 過酸化水素水とエ夕ノール水溶液中で, 形状 を制御した Pt 粒子の指向的運動（並進，回転）に関して 運動方向が反転するという結果が得られている[5]。それ ぞれの反応は Eqs. (1), (2)に示す通りであるが,

$$
\begin{aligned}
& 2 \mathrm{H}_{2} \mathrm{O}_{2} \rightarrow 2 \mathrm{H}_{2} \mathrm{O}+\mathrm{O}_{2} \\
& 2 \mathrm{CH}_{3} \mathrm{CH}_{2} \mathrm{OH}+\mathrm{O}_{2} \text { (dissolved) } \rightarrow 2 \mathrm{CH}_{3} \mathrm{CHO}+2 \mathrm{H}_{2} \mathrm{O}
\end{aligned}
$$

反応に共通した化学種として酸素が挙げられる。ただし, 酸素分子は過酸化水素の反応では生成しているのに対し エタノールの反応では消費されており, この違いが Pt 粒 子の運動方向に影響していると考えている。具体的には, 粒子表面と酸素分子の間には斥力が働いており，粒子形 状が非対称性である場合には粒子周りで反応が不均一と なり酸素濃度に偏りができ, その結果, 酸素分子濃度の 低い方向に運動すると考えている[5]。ここで本メカニズ ムは現在のところ推論であり，斥力の起源に関しても不 明である。しかしながら，別の実験系において，均一な エ夕ノール水溶液中であっても, Pt 粒子は, 偶発的に発 生した Pt 粒子密度の高い場所に向かって運動するといっ た現象がかなり高い再現性で得られている[7]。粒子濃度 が高い場所では，反応がより促進されるために周囲より 酸素濃度が低くなっていると考えられ, 粒子表面と酸素 分子の間の斥力の存在を後押しする結果となっている。 今回の系では, Pt を触媒として, エタノールと溶存酸素 を消費して水とアセトアルデヒドが生成する Eq. (2)の反 応が粒子表面で起きている。Pt 粒子近傍ではゲルに近い 側がエタノールの高濃度側となり反応がより進行する。 その結果として溶存酸素がより消費されることで粒子の 左右で溶存酸素濃度の非対称性が生じる。そして, Pt 粒 子表面と酸素分子の間での相互作用による反発力にも非 対称性が生じ, 溶存酸素の高濃度側から低濃度側, すな わちエタノールの拡散源であるゲルの方向へと Pt 粒子が 指向的に運動することで化学走性を示すと考えられる

(Fig. 4)。

\section{2 擬定常濃度勾配下での触媒粒子の観察}

3.1 節では, 非定常の濃度勾配条件で実験を行ったが, 運動機構の詳細について考察するためには濃度勾配は定 常状態であることが望ましい。本節では, 左右の液溜め

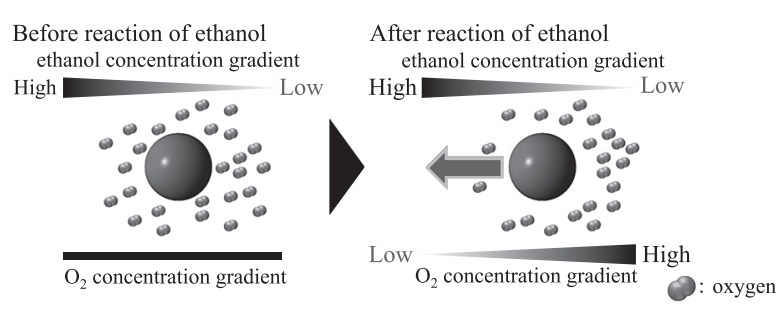

Fig. 4 Mechanism for chemotaxis of a Pt catalytic particle under ethanol concentration gradient

内の溶液濃度を一定にして, 一方からエタノールを拡散 させることで擬定常状態のエタノール濃度勾配を形成し て, Pt 触媒粒子の挙動を観察し, 定量的に解析すること を試みた。本実験系で完全な定常濃度勾配を作製するた めには, 液溜めを流通擋挥することで境界条件を一定に 保つ必要がある。しかしながら, どうしても流路内に対 流が生じてしまい, うまく観察することはできなかった。 今回は, 一次元チャネルである流路に三次元的に広がり のある液溜めを接合することで, 拡散後, 初期の短時間 であれば境界付近の濃度が保たれると考えた。また, 流 路長さを $\mathrm{mm}$ オーダーにすることで, 分オーダーで定常 状態に漸近していくことを計算上で確認している。定常 での一次元方向 $x$ の拡散方程式は, 拡散物質の濃度を $C(x)$ とすると，

$$
\mathrm{d}^{2} C(x) / \mathrm{d} x^{2}=0
$$

と書き表すことができる。境界条件（B.C.）を以下のよ うに定める。

$$
\begin{aligned}
& \text { B.C. 1: } C(x)=C_{0} \text { at } x=0 \\
& \text { B.C. 2: } C(x)=0 \text { at } x=L
\end{aligned}
$$

これらの境界条件のもと, 拡散方程式を解くと,

$$
C(x)=C_{0}(L-x) / L
$$

となる。すなわち，本実験系（Fig. 1b）を用いれば，理 想的にはエタノール濃度勾配が一定（1.0 vol\%/4.0 mm） のエタノール雲囲気が流路内に形成されることになる。

Fig. 5a (1) にエタノール濃度勾配の形成前後の Pt 粒子 の軌跡の典型例を示す。はじめ, Pt 粒子は, 均一な tertブチルアルコール水溶液中でブラウン運動をおこなって いた。その 60 秒後に, 左の液溜めにエタノール水溶液, 右の液溜めにtert-ブチルアルコール水溶液を加えたとこ ろ, Pt 粒子は図のように, エタノールの高濃度側へと向 かう指向的な運動を示した。

この $\mathrm{Pt}$ 粒子の運動の軌跡から時間幅 $\Delta t$ と平均二乗変 位 $\left\langle\boldsymbol{r}(\Delta t)^{2}\right\rangle$ (Mean Square Displacement: MSD) の関係を 求めた。平均二乗変位 $\left\langle\boldsymbol{r}(\Delta t)^{2}\right\rangle$ は, さまざまな時刻 $t$ に おいて粒子が時間幅 $\Delta t$ 間に進んだ直線距離 $|\boldsymbol{r}(t+\Delta t)-\boldsymbol{r}(t)|$ を二乗した值の統計平均である。粒子が理想的なランダ 厶運動と等速直線運動をする場合は, $\Delta t$ と $\left\langle\boldsymbol{r}(\Delta t)^{2}\right\rangle$ との 間に Eq. (7)のような関係が成立する。 

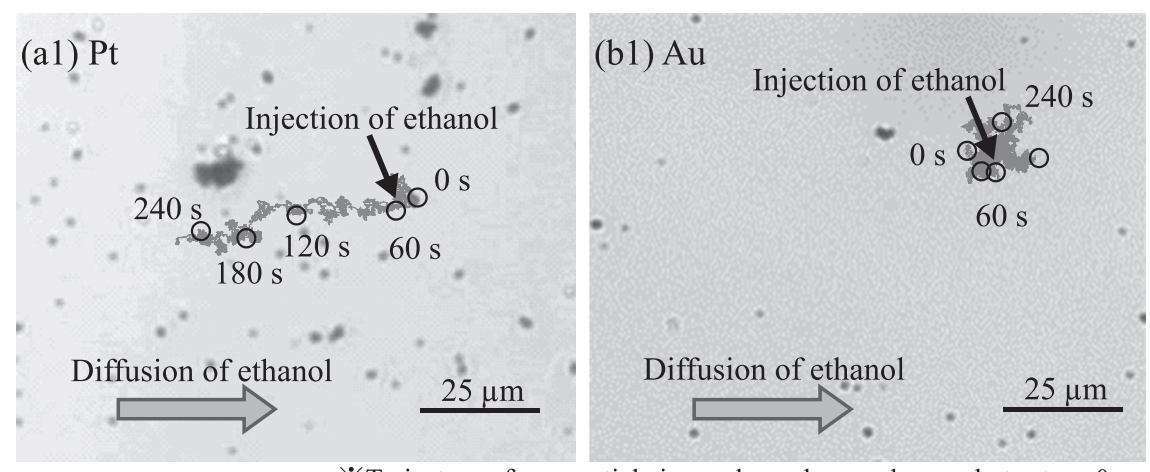

※Trajectory of one particle is overlapped on each snapshots at $t=0 \mathrm{~s}$.

(a2) $\mathrm{Pt}$

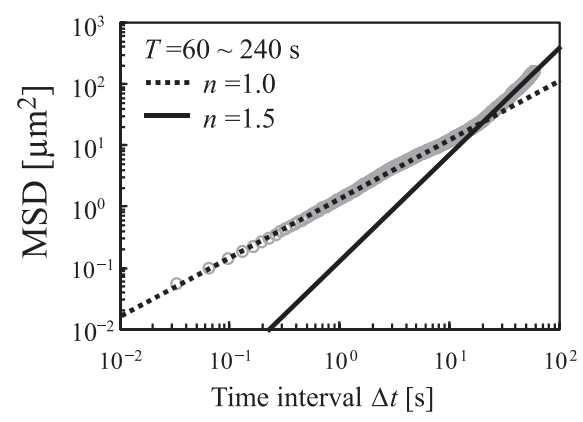

(b2) $\mathrm{Au}$

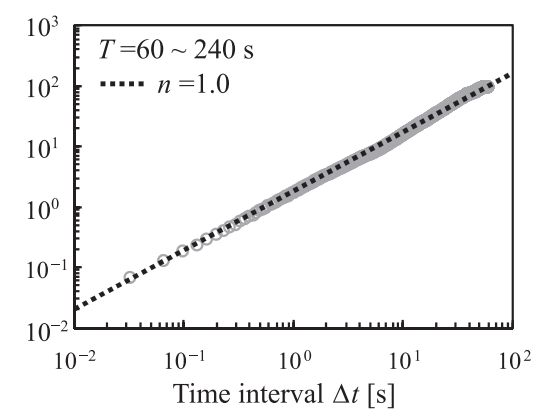

Fig. 5 Trajectory and relationship between time interval and MSD of the motion of (a) Pt and (b) Au particles under quasi-steady concentration gradient of ethanol

$\left\langle\boldsymbol{r}(\Delta t)^{2}\right\rangle=k \Delta t^{n}$

$(n=1:$ ランダム運動, $n=2:$ 等速直線運動 $)$

ここで, $k$ は比例定数である。エタノール水溶液を注入 後の $\Delta t$ と $\left\langle\boldsymbol{r}(\Delta t)^{2}\right\rangle$ との関係を両対数グラフにプロット したものを Fig. 5a (2) に示す。時間幅 $\Delta t<1 \mathrm{~s}$ の微視的な 時間スケールでは $n$ は約 1.0 である一方で, 時間幅 $\Delta t>$ $10 \mathrm{~s}$ の巨視的な時間スケールでは $n=1.5$ となった。この ことから, Pt 粒子のエタノール濃度勾配下での動特性と して, 微視的な時間スケールでは摇らぎながらランダム に運動をしているが, 巨視的な時間スケールで見ると徐々 にエタノールの高濃度側へと向かうといった化学走性を 示していることが分かった。また， $n=1$ のときに $k=2 D$ となるが, Fig. 5a (2) から見積もった拡散係数 $D$ は $0.65 \mu \mathrm{m}^{2} / \mathrm{s}$ となった。一方で, Stokes-Einsteinの式より直 径 $1 \mu \mathrm{m}$ の粒子がブラウン運動をする際の拡散係数を計 算すると $0.45 \mu \mathrm{m}^{2} / \mathrm{s}$ となる。これに関して, 球形の Pt 粒 子は, 反応溶液中では熱エネルギーに加えて, 反応から 得られた非平衡エネルギーによってブラウン運動が激化 したようなランダム運動を行い, 拡散係数が数十パーセ ント増加することをすでに報告している[4,5]。今回の系 でも，一次粒子のブラウン運動よりも 40\%程高い值を示 している観察粒子は一次粒子であると考えられる。

上述の指向的運動がエタノール注入によって発生した 対流によって発現したものではないことを確かめるため, $\mathrm{Au}$ 粒子を用いて同様の条件で対照実験を行った。 $\mathrm{Au}$ 粒 子の運動に関する実験結果を Fig. $5 \mathrm{~b}$ に示す。 $\mathrm{Au}$ 粒子は エタノール注入後もランダムに運動する様子が見られた。 実際，時間幅 $\Delta t$ と平均二乗変位 $\left\langle\boldsymbol{r}(\Delta t)^{2}\right\rangle$ の関係を調べ
ると, どの時間スケールでも $n$ はおよそ 1.0 となり, $\mathrm{Pt}$ 粒子で見られたような指向的な運動は確認できなかった。 以上の結果は, Pt 粒子の指向的運動が対流によるもので はなく, Pt 粒子周りの触媒反応によって化学走性を発現 する駆動力が生じたことを支持するものとなっている。

最後に，本実験系で作製した擬定常濃度勾配下におけ る Pt 粒子の左右でのエタノールの濃度差を見積もった。 形成したエタノール濃度勾配（1.0 vol\%/4.0 mm）から， $\mathrm{Pt}$ 粒子の粒径を $1 \mu \mathrm{m}$ として粒子の左右での濃度差を計 算すると， 〜 $10^{-4} \mathrm{vol} \%\left(\sim 10^{-4} \mathrm{M}\right)$ となった。これは溶 存酸素濃度 $\left(6 \times 10^{-4} \mathrm{M}\right)$ と同じ程度のオーダーである。 現在のところ, 定量的な評価はできていないが, Pt 粒子 はこのわずかな濃度差を検知して, 粒子の左右で溶存酸 素の濃度差を生み出すことによって, 巨視的な時間スケー ルにおいて化学走性を示していると考えられる。

\section{4. 結言}

エタノールを拡散させることで非定常濃度勾配下およ び擬定常濃度勾配下で Pt 触媒粒子の運動を観察した。そ の結果, Pt 球状粒子がエタノール濃度の高い方向へと運 動する化学走性を確認できた。また, 擬定常濃度勾配下 での観察によって, 粒子周りのエタノール濃度を定量的 に見積もることが可能になるが，粒子の左右での濃度差 はたかだか〜 $10^{-4} \mathrm{vol} \%$ であった。Pt 粒子はこのわずかな 濃度差を検知して, 巨視的な時間スケールにおいて化学 走性が発現すると考えられる。触媒粒子が反応物質濃度 の高い方向に向かう化学走性を触媒反応プロセスに組み 达むことができれば，その粒子の運動性によって総括の 
反応速度が高くなる可能性を秘めており，従前にない高 度な化学システムの構築に繋がることが期待される。
[謝辞] 本研究の予備的な段階の実験をしてくれた深堀謙 和氏および稳土昇平氏に謝意を表する。

\section{References}

[1] W. F. Paxton, K. C. Kistler, C. C. Olmeda, A. Sen, S. K. St. Angelo, Y. Cao, T. E. Mallouk, P. E. Lammert, V. H. Crespi, Catalytic nanomotors: Autonomous movement of striped nanorods, J. Am. Chem. Soc., 126 (2004) 13424-13431.

[2] D. Yamamoto, A. Shioi, Self-propelled nano/micromotors with a chemical reaction: Underlying physics and strategies of motion control, KONA Powder and Part. J., 32 (2015) 2 22.

[3] D. Yamamoto, Autonomous motions of catalytic particles in water, J. Soc. Powder Technol., Japan, 53 (2016) 717-723.

[4] D. Yamamoto, A. Mukai, N. Okita, K. Yoshikawa, A. Shioi, Catalytic micromotor generating self-propelled regular motion through random fluctuation, J. Chem. Phys., 139
(2013) 034705.

[5] D. Yamamoto, T. Takada, M. Tachibana, Y. Iijima, A. Shioi, K. Yoshikawa, Micromotors working in water through artificial aerobic metabolism, Nanoscale, 7 (2015) 1318613190.

[6] Y. Hong, N. M. K. Blackman, N. D. Kopp, A. Sen, D. Velegol, Chemotaxis of nonbiological colloidal rods, Phys. Rev. Lett., 99 (2007) 178103.

[7] M. Kubouchi, Y. Io, D. Yamamoto, A. Shioi, K. Yoshikawa, Group motion of $\mathrm{Pt}$ catalyst particles in the solution including the organic fuel, SCEJ 49th Autumn Meeting, Soc. Chem. Eng. Japan, Nagoya, 2017, PA204. 